\title{
"DO I CONTRADICT MYSELF?": PROGRESSION THROUGH CONTRARIES IN WALT WHITMAN'S "THE SLEEPERS"
}

\author{
Carol Zapata Whelan
}

\section{"Contradiction is the light of the poet."}

-Federico Garcia Lorca

"Without contraries there is no progression."

-William Blake

Walt Whitman's “The Sleepers," "the most famous dream in American literature," a vision where pain, death, and isolation "awaken" to peace, life, and unity, has produced a variety of readings which ignore the poem as a process or progression of contraries. Critics find that Whitman's imagery of death, pain, departure, and disorder throughout the first six sections of "The Sleepers," is at odds with the life-affirming "contrastive schema" or "elaborate counterpointing" of the poem's "contrived" concluding sections. "Whitman's leap of faith at the end has caused problems," acknowledges one critic. ${ }^{3}$ However, when we read "The Sleepers" as a progression of contraries and examine its contradictions, we will find that the conclusion of the poem emphasizes what the poet has been saying since the beginning of his vision.

To follow Whitman through his dream or "sleep chasings," Julia Kristeva's eclectic critical approach is helpful: her psychoanalytic definitions and emphasis on the interdependence of opposites fit a reading where "The Sleepers" leads us not, as Kerry Larson claims, "through a grief-stricken maze," but rather through Whitman's "revolving cycles in their wide sweep" that make up the movements of life. ${ }^{4}$

"The Sleepers" progresses through a flexible pattern of opposites. Whitman's familiar "I" oscillates between I-as-witness and I-as-Other through visions that move from I-as-singular to I-as-plural, young female to old widow, anonymous giant to historical giant, father to mother, night to day. If we include the poem's two deleted sections the pattern is not disrupted: a young male's voice follows the young female's voice; later a black slave's section follows the vision of a red squaw (contrasting gender, color and social state). This pattern suggests that under Whitman's apparent disorder sleeps an organic coherence.

The "I" that begins the poem's first four sections with its movements-"I wander," "I descend," "I see," "I turn"-opens the 
poem with what has been read as a purely negative declaration:

I wander all night in my vision,

Stepping with light feet, swiftly and noislessly stepping and stopping,

Bending with open eyes over the shut eyes of sleepers,

Wandering and confused, lost to myself, ill-assorted, contradictory,

Pausing, gazing, bending, and stopping. ${ }^{5}$

R.W. French interprets this wandering as pure impotence: "The Sleepers' begins with the poet as mere dreamer, caught up in his own confusion, powerless, unable to act or to respond sympathetically to the world around him." However, the speaker is literally "ill-assorted," invested with opposing elements. Without ignoring the negative cast of "confused" and "contradictory," we should note an opposing ("contradictory") current that moves the speaker. He appears "stepping with light feet." While not as buoyant as the "afoot and lighthearted" wanderer of "Song of the Open Road," this "I" comes "swiftly and noiselessly." It hovers with a quiet energy, "pausing," "gazing," "bending," "stopping," that hums through words that both signify and combat stasis: while the root words denote stillness, the present participles ring with activity.

Larson claims that this speaker is the poet impotent before his own poem, "groping for some kind of entrance into a text not clearly his own." This observation ignores the quiet, rallying effort of an "I" whose contradictory state will reflect the ill-assortment of the sleepers; whose healing authority will rely on a recognition of frailty. Whitman's wandering "I," in its undirected journey, will turn what appears to be impotence into an fluid, empathetic power. As Calvin Bedient asserts, "The Whitmanic 'I' gains its authority from being a doer, from being there, where this, that, or the other man has been, or where all have been or can be." 8 The speaker's "thereness" includes text, sleepers, reader, enfolding all in a state that like the night, like sleep, holds and hides presence.

The poem's third stanza, with figures of death, evil, and solitude, does not (as French claims) "present a sick and murderous world where to be human is to be in hell." Instead, it suggests that a self-imposed hell denies life. Whitman's lines indict the self-coiling of corruption: "The wretched features of ennuyés, the white features of corpses, the livid faces of drunkards, the sick-gray faces of onanists" ( $L G, 424)$. These "faces" and "features" of degeneration recall the "fools" in Whitman's question: "Did you ever see the fool that corrupted his or her own body?" Ennuyé, drunkard, onanist, all share in the numb collapse of the corpse. This self-isolating "fool" matches Julia Kristeva's description of the "auto-erotic": 
The auto-erotic person cannot allow himself to be loved (no more than he can let himself be lovable)... He is ... set within the shattered territories of his parcelled body, coiled up around his erogenous zones. He is indifferent to love, withdrawn in the pleasure that a provisionally reassuring diving suit gives him. ${ }^{10}$

The images that follow are of an isolation that is not a withdrawal into pleasure or provisional reassurance: "The gash'd bodies on battle-fields, the insane in their strong-door'd rooms, the sacred idiots" ( $L G, 424)$. These figures of death and isolation depict an accidental misfortune. Moreover, in contrast with the white-faced corpses, the "gash'd bodies on battlefields" evoke energy (and bravery?) felled in struggle and recall that "battles are lost in the same spirit in which they are won" $(L G, 46)$. The insane (gash'd minds) fight their own battles in "strong-door'd rooms" against a Symbolic order (in Kristeva: Law, language, culture), an architecture that they are incapable of negotiating. The sacred-idiots, on the margins of the Symbolic order, are innocence against isolation. (Do these figures depict a different sort of "fool"-brave, insane, or sacred - that resists coiling in?)

The next stanza swings in the opposite direction from solitude. Self-expansion can produce the peace and unity of the assorted pairs: married couple, sisters, friends, mother and child sleep "calmly," "lovingly." This ideal tableau begins the repetition of the word "sleep," which will braid through the next two stanzas of those isolated by physical or moral impairment. It is as if the peace of union has spilled over into the images of the isolated and unloved through the lulling repetition of "sleep":

The blind sleep, and the deaf and dumb sleep,

The prisoner sleeps well in the prison, the runaway son sleeps,

The murderer that is to be hung next day, how does he sleep?

And the murder'd person, how does he sleep?

The female that loves unrequited sleeps,

And the male that loves unrequited sleeps,

The head of the money-maker that plotted all day sleeps,

And the enraged and treacherous dispositions, all, all sleep. $(L G, 425)$

The rhythmic insistence of "sleep" works like a mantra-or an absolving prayer-as if the speaker, a sort of father confessor, sinner-forgiver, put to rest and "forgave" the faculties that stunt, block, or kill fruitful union. Larson calls Whitman's conjunctions "exaggerated juxtapositions" and claims that they "further emphasize a world closed off to all mediations." 11 Instead, the enfolding of good and bad sets off the rhythmic movement toward a unity that the end of the poem will celebrate. 
In her interpretation of Christian sin and redemption, Kristeva, citing Hegel, offers an unusual analysis of the contradictory role of abjection in a progress toward the good:

A source of evil mingled with sin, abjection becomes the requisite for a reconciliation, in the mind, between the flesh and the law. "It is at once what produces the disease, and the source of health [it is the poisoned cup in which man drinks death and putrefaction and at the same time the fount of reconciliation; indeed to set oneself up as evil is to abolish evil in oneself.]"12

Whitman himself declares, "I make the poem of evil also, I commemorate that part also, / I am myself just as much evil as good"' ( $L G, 19)$. The poet puts to sleep, as it were, the elements that corrupt and inhibit. Such elements come under the classification of Kristeva's "abjection," an expansive term that involves what the Self "ab-jects," tries to expel on a physical/moral level in order to become "clean and proper" (to become lovable?) - something ultimately unexpellable since it is a property of the Self. Whitman paradoxically defers the bad by acknowledging it as a part of the (also good) Self.

When the abjection that leads to "enraged and treacherous dispositions," "murderer," "prisoner," has been put to sleep, the darkpiercing visions of the "I" begin:

Now I pierce the darkness, new beings appear,

The earth recedes from me into the night,

I saw that it was beautiful, and I see that what is not the earth is beautiful.

I go from bedside to bedside, I sleep close with the other sleepers each in turn, I dream in my dream all the dreams of the other dreamers,

And I become the other dreamers. ( $L G, 425-426)$

As the speaker pierces the darkness of closed eyelids, he also pushes through "lids" of another sort, definitions - "the blind," "the deaf," "the prisoner" - that hide true being. Whitman's "I" will touch "new beings" that sleep behind "faces" and "features." In sleeping close with the other sleepers, in mingling with them in a state that suggests a fluid soul after death, it is as if the speaker demonstrates the "death" of an Ego that clears the way for union. Kristeva sees the Ego as a "body" that impedes love, union, and birth of Self: "An Ego is a body to be put to death, or at least to be deferred for the love of the Other so that Myself can be. Love is a death sentence that causes me to be" (Reader, 252). Death of the Ego, however, does not mean dissolution of Self in Other. Whitman does not lose the Self in, as D.H. Lawrence calls it, "the awful pudding of One identity."13 Whitman's insistent "I" never disappears through all its transformations but rather remains as distinct as the character that represents it on the page. However, the renewal of 
Self, or full being, depends on deferral of an Ego capable of closing up into abjection and denying the Self union with Other or with the Whole.

Paradoxically, the Self's union with the Whole affirms the Self's singularity and the self-love that (in a circular way) allow the Self this union. Kristeva interprets St. Thomas Aquinas on this point:

. . . in attempting to remain faithful to the Thomist perspective, one cannot overemphasize the expansion of the Self that loves itself, and thus justifies itself to the dimensions of being; love of self allows Aquinas to locate being at the heart of the Self. ... The similarity between the part and the whole, the individual and the universal, based on the good, founds for Aquinas the absolute value of singular individuality. The tremendous respect for the singular that he thus evidences rests upon the acknowledgment of an imposing aspiration for being (part of) the Whole. ${ }^{14}$

Death/sleep of Ego frees the faculty of self-love which in turn affirms the Self through love of Other and union with God and His Whole.

The dark-piercing intercourse and union that result in the jubilant "I am a dance ... . I am the ever-laughing," lead to a familiarity with the "divine journeymen" (inversely a "gay gang of blackguards") who in a carnivalesque way "make" the "I" both "boss" and "pet." However, the mirth-making of this fraternal (and even erotic) exultation is too high-pitched. A current of fear moves through all the excitement: along with a celebration of unity runs a fear of self-abandon. "The fit is whirling me fast" indicates a loss of control; "They surround me and lead me and run ahead when I walk" threatens the speaker's selfreliance. The Freudian commonplace that "Eros has, since the beginning, been permeated with Thanatos" (Reader, 248) may provide an unusual circle of logic: the "I" rejoices over a union made possible by a "death" of the Ego-body and yet fears "death" through dissolution of Self in Other (or Whole). "I am a dance" reflects the unceasing rhythm (dance) that is a moving balancing act: the Self is a "dance" of contrary forces carrying the "I" toward a union with Other and All that affirms life but that may also risk what Aquinas calls "loss of one's own."15 "I am the ever-laughing" (an echo of "ever-lasting") might suggest that laughter and dance-eruptions of the semiotic (in Kristeva, the body, the imagination, the irrational) that both subvert and affirm the laws of the Symbolic order-are a perpetual energy in the Self's struggle for union without self-extinction.

The second part of Section 1 of "The Sleepers," where love and death merge and separate in the darkness, resumes the "dance" around union. The first half of this part moves forward with desire when the speaker as young female says: "I am she who adorn'd herself and folded her hair expectantly, / My truant lover has come and it is dark" (LG, 426). Wavering, elusive, truant, the lover both arrives and disappears. "He" is a projection of the young woman's conception of him (or a 
projection of the Self), a "doubling" onto the darkness-onto a truant lover who may or may not exist. A passage from the Biblical "Song of Songs" reflects for Kristeva a similar presence in absence: "The loved one is not there, but I experience his body in a state of amorous incantation. I unite with him sensually and ideally" (Tales, 94). The mystery of the truant lover produces a distance, an implied defiance of sorts that results in the tension of ever-awake desire. Remarking on defiance and desire Kristeva asks: "Isn't such a defiance precisely a tension, what brings to view, gives voice to, turns into gesture, into poetry, the strength of desire?" (Tales, 96). The truant lover section is a "gesture" of desire.

Desire for the truant lover, however, would seem to waver with a fear that "he" could actually stay: "Darkness, you are gentler than my lover, his flesh was sweaty and panting." Is there in this address to the gentle darkness a need to hold back? Is there the virgin's delicate resistance to the sweaty, panting, real consummation of desire? Sweat and "the hot moisture that he left me," belong to a secondary category of Kristeva's abjection: bodily fluids and revulsion; as she points out, "the abject confronts us, on the one hand, with those fragile states where man strays on the territories of animal" (Horror, 12). Is there here a holding back of the Self that fears the body's materiality? The hands that "are spread forth" and that "pass in all directions" would seem to move off "sound[ing]" the "shadowy shore" of an abstract darkness (death) to leave behind body and material Other. And yet, the female voice cannot seem to dismiss the lover and his role in the dark: "I thought my lover had gone, else darkness and he are one." The voice is drawn to a summoning sound of life (Eros) heard even from the shadowy shore: "I hear the heart-beat, I follow, I fade away." Is this fading a dissolution of Self or is it a death of Ego? Does this departure lead towards or away from union? With Whitman it seems to suggest two opposing inclinations that end up working together.

In Whitman surging forward engages and lurches out of a backward pull towards hiding (fading). Whitman himself as both truant lover and expectant female offers an elusive intimacy from the "cunning covers" of his poetry; he tantalizes with his truancy: "I depart as air" ( $L G, 89)$; "Missing me one place search another / I stop somewhere waiting for you," ( $L G, 89)$. At other times the poet springs up frank and proprietary: "My left hand hooks you round the waist," "I place my hand upon you that you be my poem." Reader and poet are, after all, "amorous incantation" to one another. Loving refers to Whitman as voyeur and virgin whose "carnal omniscience" "produces the safest sex in America." 16 Bedient sees that Whitman's "fate, both privileged and prohibiting, was to be the lover of everyone ... and of no one in particular." 17 It is in this flesh made word that Whitman both eludes us 
(fades like a mirage) and unites with us sensually and ideally.

Whitman's resistance turns to poetry not only the strength of desire, but the fear of materiality (the body and its currents of Eros and Thanatos) - fear of the abject. This fear would seem to be a natural reflex, one that safeguards against "loss of one's own" in union with Other. If this reflex is too strong, it blocks expansion and union; too weak, it prevents the singularity of Self-self love that enables love of Other. Fear of and desire for Other alternate; as Kristeva says: "fear and object proceed together until the one represses the other-but in which of us is that truly successful?" (Reader, 327).

The force of Whitman's injunction to merge rises up with the desire and fear that inspire a poem like "To a Passing Stranger": "I am not to speak to you, I am to think of you when I sit alone or wake at night alone" ( $L G, 127)$. (Here is expectant female conjuring her lover; here is poet addressing his reader.) Bedient proposes that "Whitman's erotic approach to his readers was part compensation for his actual Puritanism, part strategy . . . and part profound intuition."18 This strategy would seem to arise from the intuition that a Puritan Whitman could merge all he wanted through poetry, confronting the abject without really getting too close, appearing direct (naked) to reader without having to reveal himself from behind his "cunning covers." The beauty of this strategy is in Whitman the poet's power to take advantage of the fear and desire with which Whitman the man would continue to struggle.

From "perfume and youth" of the truant lover section, Whitman's "I" descends to the wrinkled face of an old widow. This transition into (opposite) Other occurs through an interesting retention of the Self. "It is my face yellow and wrinkled instead of the old woman's" (italics mine). Moreover, as Whitman's "I" sees, it actively arrogates and animates: "A shroud I see and I am the shroud, I wrap a body and lie in the coffin" ( $L G, 427)$. The body-wrapping shroud extends the imagery of covered and uncovered, contrasting with the adolescent nakedness in the prior deleted section. ${ }^{19}$ This concealing shroud goes against the Whitmanian imperative to "undrape." This is the poet who remarks the "curious sympathy one feels when feeling with the hand the naked meat of the body" $(L G, 101)$. Without this contact, "whoever walks a furlong without sympathy, walks to his own funeral dressed in his shroud" $(L G, 86)$. The shroud hides a degenerating self-isolation: "those who corrupt their own bodies conceal themselves" ( $L G, 93)$.

In Whitman the body itself can enshroud if it conceals soul/Self from life and Other, from the human and the divine in a self-insulation that is "death" in life. "I"-as-shroud speaks: "It is dark here under ground, it is not evil or pain here, it is blank here, for reasons" ( $L G$, 427). These lines link death with blankness, nullness, loss of 
sensation - out of the "light and air."

On a textual level "blank" is the page without the body of text the poet gives it, but also "blank" is the poet without the life his page (reciprocally) returns. Kristeva observes: "I would even say that signs are what produce a body, that-and the artist knows it well-if he doesn't work, if he doesn't produce his music or his page or his sculpture, he would be quite simply, ill or not alive" (italics mine). ${ }^{20}$ The poet inscribes blankness with fear, desire, Self. The resulting "life" of page and poet as reciprocal process reflects the union that Whitman celebrates. This life-giving communion takes on another form between poet and reader: when Whitman's "I"-inflected poetry is read aloud and "reincarnated" in a living, breathing voice, reader "becomes" poet and poet "becomes" reader, overcoming blankness in time and space.

A reading of blankness as the "death" signaled by shroud and coffin need not exclude the metonymic reference to physical death. Such a reading would seem to contradict a (pre-Civil War) Whitman who considers death "different from what anyone supposed, and luckier" $(L G, 35)$. However, in his earnest defense of death, Whitman must privately balk if he is to share the fears of the multitudes he contains and the "other dreamers" that he becomes. The "light and air" are friendlier than a "dark grave" that claims the Self through its lesser forms of disease, impairment, isolation. But in his progression through contradiction, Whitman's flexible strength comes from pervading and enfolding death in the diseased, the bad, and the dead themselves ("I am a shroud") and riding fear up to "the light and air." Whitman does not ignore or deny the pain and loss of death (as proven by his critics' insistence on "The Sleepers" as a nightmare vision), but he employs these the way heaven and earth employ body and soul: to affirm and renew life. This affirmation occurs in the famous passage from "Song of Myself':

The grass is very dark to be from the white heads of old mothers,

Darker than the colorless beards of old men,

Dark to come from under the faint red roofs of mouths.

O I perceive after all so many uttering tongues,

And I perceive they do not come from the roofs of mouths for nothing.

What do you think has become of the young and old men?

And what do you think has become of the women and children?

They are alive and well somewhere .... $(L G, 34)$ 
As Whitman will demonstrate at the conclusion of "The Sleepers" where the departed return, even the dead will be "alive and well" since "All goes onward and outward, nothing collapses" $(L G, 34)$.

An image antithetical to ennuyé, onanist, and shrouded corpse appears in Section 3 of "The Sleepers"-that of the "beautiful gigantic swimmer swimming naked." In contrast to Kristeva's auto-erotic in "self-protected diving suit," the gigantic swimmer of "courageous arms" and "undaunted eyes" is the noble, expanded Self, exposed, in direct contact with the sea as archetypal image of birth and destruction. This athletic figure to be dashed on the rocks and borne away by the sea is not, as Larson says, a "Promethean over-reacher . . . Whitman's alter ego doomed for no other reason than his impulse to swim."21 Instead, the "beautiful giant" is a vision of the strength that Whitman exalts: "strength, which after all is perhaps the first, completest highest beauty." 22

Critics have emphasized the (arbitrary) destruction and loss in the swimmer's death and have seen only impotence in the speaker-alter ego. Robert K. Martin even suggests that Whitman staged the swimmer's death on a sado-masochistic impulse. ${ }^{23}$ However, the violence of the scene as a vision of life with its "swift running eddies" allows Whitman to pay tribute to the defiance of "courageous arms" and "undaunted eyes." The speaker himself rages with a force that matches the swimmer's strength against the elements: "I hate the swift running eddies that would dash him head-foremost on the rocks . . . / What are you doing you ruffianly red-trickled waves?"; but in his (partially) helpless anger runs an undercurrent that blesses strength and struggle:

\section{Steady and long he struggles,}

He is baffled, bang'd, bruis'd, he holds out while his strength holds out,

The slapping eddies are spotted with his blood, they bear him away, they roll him, swing

him, turn him,

His beautiful body is borne in the circling eddies, it is continually bruis'd on rocks,

Swiftly and out of sight is borne the brave corpse. ( $L G, 428)$

The swimmer dies fighting, like the gashed bodies on the battlefield; he "hold[s] out" even as he is "bang'd, bruis'd." Larson is mistaken in his claim that "No transcendence follows the slaying of the author's second self." 24 The swimmer's courage transcends death so that even his corpse is "brave." Moreover, his "beautiful body" is "borne swiftly and out of sight" by the amniotic waters of the sea. It is never shrouded, coffined, or confined; it becomes "unseen," but as Whitman has told us in "Song of Myself," "the unseen" will be proven by "the seen."

The questioning anger of Section 3 folds into a "baffled, bang'd, bruised" grief in Section 4: "I turn but do not extricate myself, I Confused, a past-reading, another, but with darkness yet" ( $L G, 428)$. 
The "past-reading" of the swimmer's individual death cedes to a "pastreading" of the collective death in a sinking ship. The spectacle of loss, however transcendent, makes the spirit wince and "turn" away in pain-but it is not enough to cause the "I" to "extricate myself" from experience. The following vision will roll, swing, and turn the speaker himself:

I look where the ship helplessly heeds on, I hear the burst as she strikes, I hear the howls of dismay, they grow fainter and fainter.

I cannot aid with my wringing fingers,

I can but rush to the surf and let it drench me and freeze upon me.

I search with the crowd, not one of the company is wash'd to us alive,

In the morning I help pick up the dead and lay them in rows in a barn. ( $L G, 428-429)$

The speaker's "wringing fingers" contrast with the giant's "courageous arms" (ultimately powerless over life and death); yet as a poet whose "sprawling palms cover continents," Whitman sees with "undaunted eyes," shares suffering and strength. With "original energy" that matches nature's forces the poet can pick up the dead and lay them in rows" (of verse), can help to consecrate them in the transcendence of art.

From the dying of an anonymous giant and the unknown dead laid in a barn, Whitman moves to the well-known trials of an historical "giant," George Washington. Two different events from the American Revolution combine in the same passage: the American defeat at Brooklyn is overlaid by the disbanding of a triumphant rebel army. ${ }^{25}$ Defeat precedes victory; grief and tears show in the Homeric American legend. The Washington of this scene is a hero absent from the stiff-necked portraits:

His face is cold and damp, he cannot repress the weeping drops, He lifts the glass perpetually to his eyes, the color is blanch'd from his cheeks, He sees the slaughter of the southern braves confided to him by their parents. $(L G, 429)$

This Washington is one of Whitman's "divine average"; the common man shows through the hero, just as the hero has shown through the common man in the anonymous giant. The unknown heroes share (and, Whitman believes, surpass) the nobility of the legendary. ${ }^{26}$ The weeping common man in Washington contributes to the heroic status that he shares with his "southern braves."

From a historical vision of the "father" of America, the speaker progresses in Section 6 to a personal reminiscence of "what my mother told me one day as we sat at dinner together": 
A red squaw came one breakfast time to the old homestead, On her back she carried a bundle of rushes for rush-bottoming chairs, Her hair, straight, shiny, coarse, black, profuse, half-envelop'd her face, Her step was free and elastic, and her voice sounded exquisitely as she spoke. My mother looked in delight and amazement at the stranger . . . . $(L G, 430)$

When she meets the squaw, the mother is a "nearly grown" girl, unfinished, still elastic; her love, delight, amazement before the stranger are of a Self open and fertile: "The more she looked upon her she loved her." The mother (or pre-mother) of the narration is a future bearer of "nimbler babes" (of the speaker); her love for the nobility, purity, elasticity of the squaw embraces qualities which in turn become the very characteristics of Whitman's ideal "athletic motherhood."

The squaw's departure might be interpreted as a failure in human relationships. Yet the very nature of the meeting determines its brevity. The nomadic squaw who carries rushes for unfinished chairs cannot be made to stay long on bench or homestead. She is "original energy," unfixed, uncorrupted, unrestricted, the moving soul as D.H. Lawrence finds it in Whitman: "The soul is herself when she is going on foot down the open road." 27 (Of course, Whitman himself, "the first white aboriginal," as Lawrence calls him, shares this native restlessness. $)^{28}$ To remain on the "homestead" (government land taken from the Indian) is, for the squaw, to be robbed of elastic step and to be bound in the white man's architecture. While this loss produces pain - "O my mother was loth to have her go away" - the brief communion has left an ideal image held close in memory: "All week she thought of her, she watch'd for her many a month, / She remember'd her many a winter and many a summer . . . ." This memory is passed on to son, poem, reader.

The mother's passage leads into the sublime shift of awakening and rebirth in Section 7 of "The Sleepers." "Mother night" has "brought forward" speaker and sleepers into the "light and air." What has been present all along in this mother (in the poem) now emerges, renewed and reborn. What has been asleep or submerged now bounds up:

A show of the summer softness - a contact of something unseen - an amour of the light and air,

I am jealous and overwhelm'd with friendliness,

And will go gallivant with the light and air myself. ( $L G, 430)$

Through movement to "air myself," body and soul emerge and merge with the All; as the poet observes in Specimen Days, "perhaps the inner never lost rapport we hold with earth, light, air, trees, etc, and is not to be realized through eyes and mind only, but through the whole corporeal body, which I will not have blinded or bandaged any more than the eyes." 29 The bandages that cover are shed in light and air; this shedding 
exposes all disfigurement to direct contact with and a sharing in sublime union.

Whitman's pairing of opposites and reunion of the disparate reflect the sublime transformation that yokes the deject, as Kristeva puts it, with the sparkling. The sublime moment triggers the gathering in and expansion of Section 7. Kristeva's description of sublime union and "divergence" might shed light on the exuberance of Section 7:

As soon as I perceive it, as soon as I name it, the sublime triggers-it has always already triggered-a spree of perceptions and words that expand memory boundlessly. I then forget the point of departure and find myself removed to a secondary universe, set off from the one where "I" am-delight and loss. Not at all short of but always with and through perception and words, the sublime is a something added that expands us, outstretches us and causes us to be both here as dejects and there as others and sparkling. A divergence, an impossible bounding. (Horror, 53)

It is perhaps this impossible bounding and divergence, the capacity of the speaker to exist in two universes - that of the dispossessed, that of the sparkling - that has confused critics. Larson, for example, cannot see the connection between the loss of "impotent beholder" and the delight of "magisterial figure." 30 However, these two personas are always in the process of oscillation and fusion; this is the very process that leads to the sublime. Kristeva explains the relationship of such contraries in the opposition of (impotent) "symptom" and sublimation:

In the symptom (a language that gives up . . . a cancer that the listening devices of the unconscious do not hear, for its strayed subject is huddled outside the paths of desire), the abject permeates me, I become abject. Through sublimation, I keep it under control. The abject is edged with the sublime. It is not the same moment but the same subject and speech that bring them into being. (Horror, 12)

Does Whitman's speaker become abject? Let us say that the speaker reveals what he says he assumes: the abject and the sublime through his dreamers, isolated or united, weak or strong, good or bad. He contains these multitudes that reflect all the contradictions of the Self. When the speaker says: "I am the actor, the actress, the voter, the politician" $(L G, 426)$, he wears the roles (as poet wears a mask) of those who take on roles or are defined by them. However, no one role must define or confine the Self; to allow this rigidity is to close up into an abjection that is "death" and not a spur towards the sublime. The Self must push out of the "malady" of "seems":

What is worse-what more general malady pervades each and all of us, our literature, education, attitude toward each other, (even toward ourselves) than a morbid trouble about seems (generally temporarily seems too,) and not trouble at all or hardly any about the sane, slow growing, perennial, real parts of character, books, friendship, marriage- 
humanity's invisible foundations and hold-together. (As the all-basis, the nerve, the great sympathetic, the plenum within humanity, that gives stamp to everything, is necessarily invisible). ${ }^{31}$

Whitman tries to show humanity's invisible "hold-together" at work in the conclusion of "The Sleepers." If we trouble too much over what seems to be irretrievably at odds, unrestorable, irrecuperable, then we will miss the sublime moment, the divine unifying Oversoul will seem invisible (asleep). Invisible "elements merge in the night" to retrieve all the figures that in some form departed in the poem's first sections: "The beautiful lost swimmer," "red squaw" "midnight widow," etc. The speaker announces: "The antipodes, and every one between this and them in the dark, / I swear they are averaged now-one is no better than the other, / The night and sleep have liken'd them and restored them." $(L G, 431)$ This hold-together overcomes and incorporates ugliness and chaos in progress towards unity and peace, indicating that whatever role it may assume, "The soul is always beautiful," that even the "wildest and bloodiest" has its place in a universe ordered in time and space.

In the poem's last section, a sort of merciful Judgment Day where body and soul are restored and released from obstructions, the sleepers unite and flow together: hate, fear, and isolation have led to love, desire, and unity. The speaker's therapeutic touch promotes the bodily release of the abject: what is held back, congested, plugged, blocked, paralyzed, is loosed: "stiflings and passages open." This release reflects the freeing of body and spirit that allows expansion and union not only with opposite (master/slave, scholar/teacher) but with "every one between this and them in the dark" $(L G, 431)$.

The sleepers appear in sleep, a state that isolates and resembles death. Yet Whitman has united them "hand in hand over the whole earth," and pierced through darkness, misrepresentation, and disparity to celebrate the unity and life that "sleeps" in his figures. He has in his way "put to sleep" the negative and employed it in his affirmation (awakening) of the positive. He has deferred Ego to uncover and celebrate the heart of the Self in its singularity and capacity for union. He has acknowledged the abject as a part of the Self that cannot be denied, that must instead be employed towards expansion and life. In his identification with his sleepers, in his own role as dreamer, the poetspeaker has joined with and lent strength to the "worst-suffering" and the well. As "impotent beholder," Whitman's "I" has in truth been healer and has proven that, as Lawrence says, "He was a great leader. He was a great changer of the blood in the veins of men." ${ }^{32}$ Whitman charged and changed "the blood" by not ignoring its abject elements, by using them instead to "blow grit" into body and soul. He is the poet and son who later wrote during the internal conflict that was the Civil War: "Mother, I have a real pride in telling you that I have the 
consciousness of saving quite a little number of lives by saving them from giving up and being a good deal with them." 33 In being "a good deal with" us, Whitman lends us, his sleepers, the strength to rise, to employ conflict and contradiction in the expansion of life.

\section{California State University, Fresno}

\section{NOTES}

1 Jerome Loving, "The One Book for Whitman Studies" forthcoming in Etudes Anglaises, 1992. Loving also calls attention to Whitman's love of paradox.

2 Helen Vendler, "Whitman's Placing of the Aesthetic," Delta 16 (May 1983), 30; Kerry C. Larson, Whitman's Drama of Consensus (Chicago: University of Chicago Press, 1988), 70.

3 R.W. French, "Whitman's Dream Vision: A Reading of 'The Sleepers,'" Walt Whitman Quarterly Review 8 (Summer 1990), 14. For example, Helen Vendler finds the poem's Section 7, with "its diagram of the universe as one of antipodes," overly symmetrical and limiting and believes that these antipodes produce a conclusion that "goes on to enact, in a way we may not find wholly satisfactory, the beauty it has asserted" (Vendler, 27). In Whitman the Political Poet (New York: Oxford University Press, 1989), 124, Betsy Erkkila feels that "Whitman's declaration of faith is a declaration by fiat" because "his assertion of unity is at odds with his confused and ill assorted dream vision of a universe in which everything is not in order and diversity does not cohere." Finally, Kerry Larson maintains that the poet's emphasis on opposites mars the poem's form: "The closer the poem draws toward a vision of restored union, the more tendentious and artificial its structure becomes" (Larson, 70).

4 Larson, 69.

5 All quotations from Whitman's poetry are from Leaves of Grass, ed. Harold W. Blodgett and Sculley Bradley (New York: New York University Press, 1965), 424; henceforth $L G$.

6 French, 5.

7 Larson, 60.

8 Calvin Bedient, "Whitman's Orality of Power," Delta 16 (May 1983), 84.

9 French, 5.

10 Julia Kristeva, The Kristeva Reader, ed. Toril Moi (New York: Columbia University Press, 1986), 251-252; henceforth, Reader.

11 Larson, 60.

12 Julia Kristeva, Powers of Horror: An Essay in Abjection, trans. Leon S. Roudiez (New York: Columbia University Press, 1982), 127-128; henceforth, Horror.

13 D.H. Lawrence, "Whitman," in Studies in Classic American Literature (New York: Thomas Seltzer, 1923), 246.

14 Julia Kristeva, Tales of Love, trans. Leon S. Roudiez (New York: Columbia University Press, 1987), 176; henceforth, Tales. 
15 Kristeva attributes this expression to Aquinas and interprets him in Tales of Love, 170-187.

16 Jerome Loving, "Whitman's Idea of Women," Mickle Street Review 11 (1989), 24.

17 Bedient, 91.

18 Bedient, 93.

19 See the "wet dream" deleted section in Walt Whitman, Walt Whitman's Blue Book (Facsimile), ed. Arthur Golden (New York: Astor, Lennox, and Tilden Foundations, 1968), 1:430.

20 Perry Meisel, "Interview with Julia Kristeva," trans. Margaret Waller, quoted by John Lechte in Abjection, Melancholia, and Love: The Work of Fulia Kristeva, ed. John Fletcher and Andrew Benjamin (London and New York: Routledge Press, 1990), 25.

21 Larson, 64.

22 Walt Whitman, Leaves of Grass and Selected Prose Works, ed. John Kouwenhoven (New York: Random House, 1950), 645.

23 Robert K. Martin, The Homosexual Tradition in American Poetry (Austin: University of Texas Press, 1979), 43.

24 Larson, 65.

25 Vendler points this out, 29.

26 "... I find in them the real, precious and royal ones of this land," says Whitman; see Edwin Haviland Miller, ed., Selected Letters of Walt Whitman (Iowa City: University of Iowa Press, 1990), 79.

27 Lawrence, 257.

28 Lawrence, 255.

29 Whitman, Leaves of Grass and Prose Works, 659.

30 Larson, 72.

31 Whitman, Leaves of Grass and Selected Prose, 645.

32 Lawrence, 254.

33 Whitman, Letters, 68. 